\title{
PERLINDUNGAN HUKUM BAGI PEKERJA DENGAN PERJANJIAN KERJA TIDAK TERTULIS PADA PERUSAHAAN PEMBERI KERJA
}

\author{
Robertus Berli Puryanto, I Nyoman Putu Budiartha, Ni Made Puspasutari Ujianti \\ Fakultas Hukum Universitas Warmadewa, Denpasar-Bali, Indonesia
}

\begin{abstract}
Abstrak
Tenaga kerja merupakan hal yang diperlukan suatu perusahaan pemberi kerja dalam melaksanakan kegiatan ekonominya. Hal tersebut dapat dilihat dalam pengaturan konstitusi negara Republik Indonesia pada Pasal 27 ayat (2) Undang-Undang Dasar Negara Republik Indonesia 1945. Dalam pelaksanaan hubungan kerja antara pekerja dengan perusahaan pemberi kerja tersebut ada beberapa hak dan kewajiban yang wajib dipenuhi antara kedua belah pihak. Karena adanya ketentuan mengenai perjanjian kerja yang dibedakan berdasarkan bentuk perjanjiannya maka setiap pekerja memiliki hak yang berbeda dimana hak tersebut harus dijamin oleh perusahaan berdasarkan undang-undang. Dari hal tersebut permasalahan yang akan diteliti adalah perlindungan hukum bagi pekerja dengan perjanjian kerja tidak tertulis pada perusahaan pemberi kerja, serta upaya hukum yang dapat dilakukan oleh pekerja dengan perjanjian tidak tertulis dalam hal terjadi pelanggaran hak oleh perusahaan. Metode penelitian yang digunakan adalah penelitian hukum normatif, yaitu penelitian hukum yang dilakukan dengan cara meneliti bahan pustaka yang ada. Dengan mengkaji permasalahan dengan melihat peraturan-peraturan yang ada, serta menggambarkan permasalahan yang terjadi dalam praktek atau dalam kehidupan sehari-hari di masyarakat. Dari penelitian yang dilakukan diperoleh hasil yaitu perlindungan hukum bagi pekerja dengan perjanjian kerja tidak tertulis pada perusahaan pemberi kerja diatur berdasarkann UndangUndang nomor 13 tahun 2003 tentang ketenagakerjaan dimana yang menjadi dasar adalah perjanjian kerja yang berlaku adalah perjanjian kerja waktu tidak tertentu sehingga hak-hak yang diperoleh berdasarkan ketentuan undang-undang tersebut. Kemudian upaya yang dapat dilakukan apabila terjadi pelanggaran hukum dalam hubungan kerja adalah berdasarkan Undang-Undang Nomor 20 tahun 2004 Tentang Penyelesaian Perselisihan Hubungan Industri yaitu berupa perundingan Bipartit, Tripartit (Mediasi, Konsoliasi, dan Arbitrase), serta melalui Persidangan pada Pengadilan Hubungan Industrial.
\end{abstract}

Kata Kunci: Hubungan Kerja; Perusahaan; Pekerja.

\begin{abstract}
Labor is something that is needed by an employing company in carrying out its economic activities. This can be seen in the constitutional arrangements of the Republic of Indonesia in Article 27 paragraph (2) of the 1945 Constitution of the Republic of Indonesia. In the implementation of the working relationship between workers and the employing company, there are several rights and obligations that must be fulfilled between the two parties. Because there are provisions regarding work agreements that are differentiated based on the form of the agreement, each worker has different rights where these rights must be guaranteed by the company based on law. From this, the problems that will be examined are legal protection for workers with an unwritten work agreement at the employing company, as well as legal remedies that can be taken by workers with an unwritten agreement in the event of a violation of rights by the company. The research method used is normative legal research, namely legal research conducted by examining existing library materials. By examining problems by looking at existing regulations, and describing problems that occur in practice or in everyday life in society. From the research conducted, it was found that legal protection for workers with an unwritten work agreement at the employing company is regulated based on Law Number 13 of 2003 concerning Manpower where the basis is that the applicable work agreement is an indefinite work agreement so that the rights obtained under the provisions of the law. Then efforts that can be made if there is a violation of the law in work relations is based on Law Number 20 of 2004 concerning Industrial Relations Dispute Settlement, namely in the form of Bipartite, Tripartite (Mediation, Consoliation and Arbitration) negotiations, as well as through Trials at the Industrial Relations Court.
\end{abstract}

Keywords: Employment Relations; Company; Worker. 


\section{PENDAHULUAN}

Tenaga dan kemampuan dari pekerja merupakan hal yang dibutuhkan oleh penyedia kerja dalam menjalankan perusahaannya. Sebab dan akibat dari hal tersebut adalah dimana dalam suatu waktu penyedia kerja tidak lagi memerlukan tenaga dan kemampuan yang dimiliki oleh tenaga kerja sehingga penyedia kerja dapat seenaknya memutuskan hubungan kerja dengan alasan tenaga kerja tersebut tidak diperlukan lagi (Adillah \& Anik, 2015; Asyahdie, 2013). Oleh karena itu pemerintah sebagai pembuat undang-undang, dapat turut serta melindungi pihak yang lemah (pekerja) dari itikad tidak baik yang dapat dilakukan oleh penyedia kerja, guna menempatkannya pada kedudukan yang layak sesuai dengan harkat dan martabat manusia (Budiartha, 2016). Selain hal tersebut diatas, kepastian hukum juga perlu diperhatikan bagi para pekerja yang tidak memiliki perjanjian kerja tidak tertulis (Setyawati, Ali, \& Rasyid, 2017).

Berdasarkan hal tersebut di atas maka penelitian ini dirumuskan untuk mengetahui bagaimana perlindungan hukum bagi pekerja dengan perjanjian kerja tidak tertulis pada perusahaan pemberi kerja, dan untuk mengetahui upaya hukum apa yang dapat dilakukan oleh pekerja dengan perjanjian tidak tertulis dalam hal terjadi pelanggaran hak oleh perusahaan.

\section{METODE PENELITIAN}

Metode penelitian yang digunakan dalam penelitian ini adalah penelitian hukum secara normatif. Pendekatan masalah yang digunakan dalam hal ini menggunakan dua pendekatan yaitu pendekatan Konseptual dan Pendekatan perundang-undangan (Soekanto \& Mamudji, 2006). Bahan hukum dalam yang digunakan dalam penelitian ini adalah terdiri dari bahan hukum primer, yaitu: a) UndangUndang Dasar Negara Republik Indonesia tahun 1945, b) Kitab Undang-Undang Hukum Perdata, c) Undang-Undang Republik Indonesia Nomor 13 Tahun 2003 tentang Ketenagakerjaan, d) UndangUndang Republik Indonesia Nomor 2 Tahun 2004 tentang Penyelesaian Perselisihan Hubungan Industrial, e) Undang-Undang Republik Indonesia Nomor 30 Tahun 1999 tentang Arbitrase Dan Alternatif Penyelesaian Sengketa, f) Undang-Undang Republik Indonesia Nomor 3 Tahun 1992 Tentang Jaminan Sosial Tenaga Kerja, g) Undang-Undang Republik Indonesia Nomor 1 Tahun 1970 tentang Keselamatan Kerja, h) Undang-Undang Republik Indonesia Nomor 21 tahun 2000 tentang serikat pekerja, i) Keputusan Menteri Tenaga Kerja dan Transmigrasi Republik Indonesia Nomor: KEP.100/MEN/VI/2004 tentang Ketentuan Pelaksanaan Perjanjian Kerja Waktu Tertentu. Dan bahan hukum sekunder yaitu materi hukum yang memberikan penjelasan dan analisis mengenai bahan hukum primer yang meliputi buku-buku literatur, artikel, makalah, serta internet yang berhubungan dengan perlindungan hukum bagi pekerja dengan perjanjian kerja tidak tertulis pada perusahaan pemberi kerja.

Teknik pengumpulan bahan hukum dilakukan dengan studi kepustakaan dengan menggunakan kartu catatan dan sistem file, membaca buku-buku, literatur, mengkaji berbagai peraturan PerundangUndangan yang berkaitan dengan ketenagakerjaan serta perlindungan hukum bagi pekerja dengan perjanjian kerja tidak tertulis pada perusahaan pemberi kerja (Sulistyowati \& Shidarta, 2009). Bahan hukum yang dikumpulkan, kemudian diolah dan dianalisis dengan cara interpretasi dan argumentasi hukum terhadap suatu hak dan kewajiban yang sesuai dengan sifat data yang terkumpul dan kemudian disajikan secara deskriptif analisis yaitu disajikan dengan apa adanya serta diberikan uraian-uraian dengan penafsiran untuk selanjutnya disajikan secara deskriptif (Waluyo, 2002).

\section{HASIL PENELITIAN DAN PEMBAHASAN}

Dalam pasal 51 ayat (1) undang-undang ketenagakerjaan dijelaskan bahwa perjanjian kerja yang akan dibuat oleh pekerja dengan penyedia kerja dapat dibuat dalam bentuk tertulis atau tidak tertulis. Bentuk perjanjian tersebut akan mempengaruhi bentuk hubungan kerja antara pekerja dan pemberi kerja. Dalam undang-undang ketenagakerjaan terdapat dua bentuk perjanjian yang dapat dibuat oleh pekerja dan pemberi kerja yaitu dalam bentuk perjanjian kerja waktu tertentu (PKWT) dan dalam bentuk perjanjian kerja waktu tidak tertentu (PKWTT). Dalam Pasal 57 ayat (1) undang-undang ketenagakerjaan disebutkan bahwa bentuk perjanjian kerja waktu tertentu harus dibuat dengan Bahasa Indonesia dan menggunakan huruf latin yang jelas. Oleh karena itu perjanjian kerja yang memiliki batas waktu tertentu, wajib menggunakan perjanjian dalam bentuk perjanjian tertulis. Kemudian dalam ayat (2) disebutkan bahwa Perjanjian kerja yang dibuat untuk waktu tertentu yang dibuat dalam bentuk tidak tertulis merupakan hal yang bertentangan dengan ketentuan yang dimaksud dalam ayat 
(1) tersebut diatas maka perjanjian kerja yang dibuat oleh pekerja dengan penyedia kerja tersebut dapat dinyatakan sebagai perjanjian kerja untuk waktu tidak tertentu. Sehingga dapat dikatakan bahwa pekerja yang tidak memiliki perjanjian kerja tertulis pada perusahaan pemberi kerja akan memiliki hubungan kerja dengan perusahaan pemberi kerja dengan jenis perjanjian kerja waktu tidak tertentu.

Segala hak dan kewajiban pekerja mengikuti ketentuan yang termuat dalam undang-undang ketenagakerjaan yang mengatur mengenai perjanjian kerja waktu tidak tertentu sebagai berikut:

1. Dalam Pasal (6) menyebutkan bahwa setiap pekerja yang bekerja pada penyedia kerja berhak memperoleh perlakuan yang sama tanpa diskriminasi dari pemberi kerja atau pihak lainnya yang berkaitan.

2. Dalam Pasal (60) menyatakan bahwa pekerja waktu tidak tertentu pada awal pelaksanaan hubungan kerja melaksasnakan masa percobaan selama 3 (tiga) bulan dan diberikan upah tidak kurang dari upah minimum yang berlaku.

3. Dalam Pasal (63), pekerja berhak memperoleh Surat pengangkatan dari perusahaan yang didalamnya termuat keterangan sebagai berikut:

1. Nama pekerja dan alamat pekerja;

2. Tanggal pekerja mulai bekerja;

3. Jenis pekerjaan yang dilakukan oleh pekerja; dan

4. Besarnya upah yang diterima oleh pekerja.

4. Dalam Pasal (78) menyatakan pekerja memperoleh upah kerja lembur sesuai dengan ketentuan yang berlaku antara pengusaha dan pekerja.

5. Dalam Pasal (79) menyatakan pekerja berhak atas cuti dalam 12 (dua belas) hari kerja, untuk pekerja dengan masa kerja 12 (dua belas) bulan dan istirahat selama 60 (enam puluh) hari kerja untuk pekerja dengan masa kerja 6 (enam) tahun.

6. Dalam Pasal (85) pekerja wajib tidak bekerja pada hari libur resmi, apabila pekerja bekerja pada hari tersebut maka pekerja berhak memperoleh upah kerja lembur sesuai dengan perjanjian kerja yang telah disepakati.

7. Dalam Pasal (86), tiap pekerja berhak untuk memperoleh keselamatan kerja, perlindungan serta kesehatan kerja, moral dan kesusilaan, serta yang sesuai dengan harkat dan martabat manusia serta sesuai dengan nilai-nilai agama.

8. Dalam Pasal (156), dinyatakan bahwa pekerja berhak untuk memperoleh uang pesangon apabila pengusaha melakukan pemutusan hubungan kerja dengan alasan tertentu.

Hak-hak tersebut merupakan suatu kewajiban bagi pengusaha dalam melakukan hubungan kerja dengan pekerja menggunakan perjanjian tidak tertulis/ lisan. Selain memiliki hak, tentu saja pekerja memiliki kewajiban dalam melaksanakan hubungan kerja pada perusahan tempatnya bekerja agar memperoleh hak-hak tersebut. Dalam Kitab Undang-undang Hukum Perdata terdapat ketentuanketentuan mengenai kewajiban pekerja yang diatur dalam Pasal 1603, 1603a, 1630b dan 1603c, yaitu adalah sebagai berikut:

1. Pekerja memiliki kewajiban untuk melakukan pekerjaan, melakukan pekerjaan tersebut merupakan tugas utama dari pekerja yang wajib dilaksanakan agar memperoleh haknya sebagai pekerja, namun dengan seijin pemberi kerja, pekerja dapat memberikan pekerjaannya kepada perwakilannya.

2. Pekerja berkewajiban untuk mentaati segala aturan dan petunjuk dari pemberi kerja dalam melaksanakan tugas atau pekerjaannya.

3. Pekerja berkewajiban membayar denda dang anti rugi apabila pekerja melakukan perbuatan yang dapat merugikan pemberi kerja baik karena kesengajaan ataupun kelalaian yang sesuai dengan prinsip hukum pekeerja.

Pasal-pasal tersebut diatas adalah beberapa hak yang dimiliki oleh pemberi kerja yang diterima dari pekerja yang merupakan aturan atau ketentuan yang memberikan batasan atau aturan bagi pekerjanya dalam melaksanakan kewajibannya bekerja. Hak perusahaan tersebut merupakan kewajiban bagi pekerja yang melakukan hubungan kerja dengan persuahaan pemberi kerja. Kemudian perlindungan hukum merupakan perlindungan terhadap hak asasi manusia yang dilanggar oleh orang lain sehingga menyebabkan hak asasi manusia tersebut hilang. Pemberian perlindungan hukum tersebut diberikan kepada masyarakat agar mereka tidak kehilangan hak-hak yang mereka miliki yang dijamin oleh hukum (Shalihah, 2017). Perlindungan hukum juga merupakan upaya-upaya hukum yang diberikan oleh apparat penegak hukum kepada masyarakat agar dapat memberikan rasa 
aman baik secara pikiran, mental, maupun fisik sehingga terhindar dari ancaman pihak yang tidak memiliki itikad baik. Secara teori dalam ketenagakerjaan ada 3 (tiga) jenis perlindungan yaitu: 1) Perlindungan sosial, 2) Perlindungan teknis, 3) Perlindungan ekonomis. Untuk melaksanakan segala ketentuan tersebut pemerintah telah menggunakan perlindungan secara represif dengan membuat suatu aturan yang mengatur mengenai penyelesaian terhadap perselisihan hubungan kerja dengan menerbitkan Undang-undang Republik Indonesia Nomor 2 Tahun 2004 tentang Penyelesaian Perselisihan Hubungan Industrial (selanjutnya dalam hal ini disebut undang-undang penyelesaian perselisihan hubungan industrial). Dalam Pasal 1 ayat (17) disebutkan bahwa dalam penyelesaian perselisihan tersebut dibentuk suatu peradilan khusus yang dibentuk dilingkungan pengadilan negeri yang berwenang untuk memeriksa, mengadili dan memberikan putusan terhadap perselisihan yang terjadi dalam hubungan industrial. Upaya hukum yang dapat dilakukan oleh pekerja dengan perjanjian tidak tertulis dalam hal terjadinya suatu perselisihan hubungan kerja adalah sebagai berikut: 1) Melalui perundingan Bipartit yang dilakukan oleh pekerja dengan perusahaan pemberi kerja. 3) Melalui perundingan Tripartit, dimana dalam hal ini dibedakan menjadi Mediasai, Konsiliasi, dan Arbitrase, dan melalui proses pengadilan.

\section{SIMPULAN DAN SARAN \\ 1. Simpulan}

Setiap manusia memiliki kesamaan dan kesetaraan dihadapan hukum baik itu sebagai pekerja ataupun pemberi kerja. Kedua belah pihak ini dalam kehidupan bermasyarakat memiliki suatu peranan penting. Dengan adanya pengusaha, roda perekonomian negara idi dapat terus berputar, pun pengusaha dapat terus menjalankan usahanya dengan mempekerjakan tenaga kerja dalam pelaksanaannya. Hubungan tersebut diesbut dengan hubungan kerja. Sesuai dengan undang-undang ketenagakerjaan, hubungan kerja tersebut berdasarkan pada perjanjian kerja. Dalam pelaksanaan perjanjian kerja ini, terdapat dua jenis perjanjian yaitu perjanjian tertulis dan lisan. Dalam ketentuan perundangan-undangan disebut Perjanjian Kerja Waktu Tertentu (PKWT) dan Perjanjian Kerja Waktu Tidak Tertentu (PKWTT), beberapa hal yang membedakannya adalah mengenai tugas, hak pengusaha terhadap pekerja dan hak pekerja terhadap pengusaha. Khusus dalam permasalahan mengenai perlindungan hukum bagi pekerja dengan perjanjian kerja tidak tertulis pada perusahaan pemberi kerja adalah sebagai berikut.

1. Perlindungan hukum bagi pekerja dengan perjanjian kerja tidak tertulis pada perusahaan pemberi kerja telah jelas diatur berdasarkan undang-undang. Dalam Pasal 57 ayat (1) undang-undang ketenagakerjaan disebutkan bahwa bentuk perjanjian kerja waktu tertentu harus dibuat dengan Bahasa Indonesia dan menggunakan huruf latin yang jelas. Oleh karena itu perjanjian kerja yang memiliki batas waktu tertentu, wajib menggunakan perjanjian dalam bentuk perjanjian tertulis. Kemudian dalam ayat (2) disebutkan bahwa Perjanjian kerja yang dibuat untuk waktu tertentu yang dibuat dalam bentuk tidak tertulis merupakan hal yang bertentangan dengan ketentuan yang dimaksud dalam ayat (1) tersebut diatas maka perjanjian kerja yang dibuat oleh pekerja dengan penyedia kerja tersebut dapat dinyatakan sebagai perjanjian kerja untuk waktu tidak tertentu. Sehingga menunjuk pada hal ini pekerja dengan perjanjian tidak tertulis tersebut menurut hukum merupakan karyawan tetap pada perushaan pemberi kerja. Maka berdasarkan pasal 63 ayat (1) undang-undang ketenagakerjaan, perusahaan pemberi kerja wajib memberikan surat pengangkatan yang merupakan hak pekerja dengan perjanjian tidak tertulis. Dengan ketentuan perjanjian kerja tidak tertentu tersebut pekerja akan menerima hak dan kewajibannya sebagai karyawan tetap pada perusahaan pemberi kerja.

2. Upaya hukum yang dapat dilakukan oleh pekerja dengan perjanjian kerja tidak tertulis dalam hal terjadi suatu perselisihan hubungan kerja adalah sebagai berikut:

1. Melalui perundingan Bipartit yang dilakukan oleh pekerja dengan perusahaan pemberi kerja.

2. Melalui perundingan Tripartit, dimana dalam hal ini dibedakan menjadi Mediasai, Konsiliasi, dan Arbitrase.

3. Melalui proses pengadilan.

\section{Saran}

Ketenagakerjaan merupakan suatu hal yang penting dalam perkembangan negara kita ini. Diperlukan suatu semangat kebersamaan dan persatuan dalam pelaksanaan kegiatan ekonomi. Salah satu hal yang 
paling penting adalah bagaimana hubungan pekerja dengan perusahaan dapat berjalan dengan baik. Perusahaan dalam pelaksanaan kegiatan memerlukan pekerja. Apabila dalam pelaksanaan hubungan kerja, pengusahaa tidak memperhatikan hak pekerja tentu pekerja tersebut tidak akan bekerja dengan baik. Hal ini tentu akan berdampak pada hasil kegiatan usaha. Namun karena persaingan kerja yang begitu ketat, tenaga kerja begitu saja menerima sebuah tawaran pekerjaan. Walaupun tanpa suatu perjanjian yang jelas (perjanjian tidak tertulis) tenaga kerja tersebut akan menerimanya karena himpitan ekonomi. Memang untuk menanggung hak pekerja tetap sangat berat dan mengeluarkan biaya yang besar. Perusahaan tentu terlebih dahulu bisa memberikan suatu masa percobaan untuk menetukan apakah tenaga kerja yang ia terima dapat melaksanakan tugasnya dengan baik, hal tersebut telah diatur dalam undang-undang. Namun apabila perusahaan tidak secara terus menerus memerlukan tenaga kerja yang besar, adanya perjanjian tertulis terhadap pekerja dengan perusahaan akan memeberikan solusi yang baik antara kedua belah pihak. Dalam pelaksanaannya pemerintah memang harus memberikan perhatian kepada tenaga kerja. Dengan memberikan pelatihan dan pendidikan yang ketat agar memperoleh sumber daya manusia yang baik dan dapat ditempatkan pada bidang-bidang strategis yang diperlukan oleh negara. Tentunya dalam hal ini tujuannya adalah tenaga kerja tersebut dapat bekerja dengan baik dan melaksanakan kewajibannya dengan biak pula. Pemerintah juga wajib memberikan sosialisais yang berguna bagi pekerja mengenai hak dan kewajibannya serta pentingnya memiliki serikat pekerja sebagai wadah untuk memastikan pelaksanaan hubungan kerja berjalan dengan baik. Pengawasan dari pemerintah tentu diperlukan dalam pelaksanaan hubungan kerja serta memastikan ketentuan yang ada dapat sesuai dengan perkembangan jaman.

\section{DAFTAR PUSTAKA}

Adillah, S. U., \& Anik, S. (2015). Kebijakan Jaminan Sosial Tenaga Kerja Sektor Informal Berbasis Keadilan Sosial untuk Meningkatkan Kesejahteraan. Yustisia, 4(3), 558-580.

Asyahdie, Z. (2013). Aspek-aspek Hukum Jaminan Sosial Tenaga Kerja di Indonesia. Jakarta: PT RajaGrafindo Persada.

Budiartha, I. N. P. (2016). Hukum Outsourcing Konsep Alih Daya Bentuk Perlindungan Hukum dan Kepastian Hukum. Malang: Setara Press.

Setyawati, D. A., Ali, D., \& Rasyid, M. N. (2017). Perlindungan Bagi Hak Konsumen dan Tanggung Jawab Pelaku Usaha dalam Perjanjian Transaksi Elektronik. Syiah Kuala Law Journal, 1(3), 33-51.

Shalihah, F. (2017). Perjanjian Kerja Waktu Tertentu (PKWT) dalam Hubungan Kerja Menurut Hukum Ketenagakerjaan Indonesia dalam Perspektif HAM. Uir Law Review.

Soekanto, S., \& Mamudji, S. (2006). Penelitian Hukum Normatif Tinjauan Singkat. Jakarta: Rajawali Pers.

Sulistyowati, \& Shidarta. (2009). Metode Penelitian Hukum. Bogor: Yayasan Pustaka Obor.

Waluyo, B. (2002). Penelitian Hukum Praktek. Jakarta: Sinar Grafika. 